\title{
PEMETAAN USAHA KELOMPOK TERNAK MENGGUNAKAN MODEL BISNIS KANVAS PADA SEKOLAH PETERNAKAN RAKYAT (SPR) DI KABUPATEN MUARA ENIM
}

\section{Business Model Mapping for Sekolah Peternakan Rakyat (SPR) at Muara Enim District}

\author{
Andi Nurmala Suardi ${ }^{1)^{*}}$, Eko Ruddy Cahyadi ${ }^{2)}$, Abdul Basith ${ }^{3)}$ \\ 1) 2) 3) Manajemen Pascasarjana Institut Pertanian Bogor \\ E-mail: andinurmalasuardi@gmail.com
}

\begin{abstract}
The business carried out by livestock groups on the SPR is currently very limited. Livestock groups need strategies to develop their livestock groups with SPR. Strategy requires mapping activities to be done to realize the goals SPR wants to achieve with livestock groups. Mapping livestock business groups mapped using a canvas business model. The business model of the canvas has 9 elements that must be filled in accordance with the current conditions owned by the cattle group with the SPR. The mapping of the development effort to be carried out is also poured into the canvas business model to see what a group needs in its development. Based on the mapping results there are several products, activities and additional resources that must be owned by livestock groups with SPR. In addition, costs and sources of income also increase along with the increase of products offered to customers.
\end{abstract}

Keywords: business development, groups of livestock, SPR, the business model canvas

Diterima: 20 Agustus 2018 / Disetujui: 9 Mei 2019

\section{PENDAHULUAN}

Pemerintah Indonesia sejak tahun 2005 telah mencanangkan swasembada daging sapi, yaitu impor tidak lebih $10 \%$ dari total konsumsi daging. Sampai saat ini, swasembada daging sapi masih belum tercapai dengan berbagai permasalahan yang dihadapi.Alternatif pilihan untuk memenuhi kebutuhan konsumsi daging yang terus meningkat dengan sapi impor karena harga yang lebih murah dibandingkan dengan harga daging sapi lokal menjadi pesaing berat bagi para peternak sebagai produsen utama daging sapi lokal. Tabel 1 menunjukkan total produksi dan kebutuhan konsumsi daging sapi. 
Tabel 1.Data konsumsi daging dan total produksi daging sapi

\begin{tabular}{ccc}
\hline Tahun & Total Produksi Daging Sapi (ribu ton) & $\begin{array}{c}\text { Total Konsumsi Daging Sapi (ribu } \\
\text { ton) }\end{array}$ \\
\hline 2013 & 383,32 & 559,55 \\
2014 & 395,14 & 594,36 \\
2015 & 407,29 & 632,88 \\
2016 & 419,82 & 674,96 \\
\hline
\end{tabular}

Sumber: RPJMN

Program swasembada daging sapi telah dicanangkan selama dua periode (5 tahunan), dan terakhir ditargetkan tercapai pada 2010 melalui berbagai terobosan, namun upaya tersebut belum berhasil. Menurut (Yusdja, 2009) ketidak-berhasilan swasembada daging yang dicanangkan pada tahun 2000 dan berakhir pada 2004 disebabkan tidak tercapainya sasaran program. Penyebabnya adalah: 1) kebijakan program tidak disertai dengan rencana operasional yang rinci dan kegiatan riil di lapangan, 2) program bersifat top down dan berskala kecil dibandingkan dengan sasaran yang ingin dicapai, 3) strategi implementasi program disamaratakan dengan tidak memprioritaskan wilayah unggulan, tetapi berorientasi pada komoditas unggulan, 4) implementasi program tidak memungkinkan untuk mengevaluasi dampak program, dan 5) program tidak secara jelas memberikan dampak pada pertumbuhan populasi ternak secara nasional.

Selanjutnya, dicanangkan program swasembada daging sapi dan kerbau (PSDSK) yang diharapkan dicapai pada tahun 2014.Program tersebut didukung oleh berbagai terobosan dalam inovasi teknologi, kelembagaan, dan kebijakan. Strategi percepatan swasembada daging sapi dan kerbau yang dicanangkan Direktorat Jenderal Peternakan (Ditjennak)dilakukan melalui kegiatan teknis, yang meliputi 1) pengembangan sentra perbibitan dan penggemukan, 2) revitalisasi kelembagaan dan SDM di lapangan, dan 3) dukungan sarana dan prasarana, serta kegiatan nonteknis seperti dukungan finansial dan pengembangan wilayah (Pertanian, 2009).

Berdasarkan kondisi tersebut, Lembaga Penelitian dan pengabdian pada Masyarakat (LPPM) Institut Pertanian Bogor yang sejak tahun 2013 telah mengembangkan Sekolah Peternakan Rakyat (SPR) ikut mengembangkan kelompok ternak sapi. SPR menaungi kelompok ternak dengan tujuan untuk memberikan ilmu pengetahuan kepada masyarakat skala peternak untuk mengetahui dengan baik teknis dan non-teknis peternakan yang melandasi terwujudnya kelompok kolektif dalam satu manajemen SPR akan dikelola oleh satu menejer dalam mewujudkan pemenuhan konsumsi daging, meningkatkan daya saing usaha peternakan yang bergabung di dalamnya (Penelitian, 2015). SPR diharapkan dapat membantu para peternak untuk mengembangkan bisnis peternakannya.SPR bekerjasama dengan akademis untuk membuat bahan penunjang pembelajaran kepada petenak, melakukan pendampingan, dan evaluasi kegiatan pembelajaran.Selanjutnya, SPR mengembangkan bisnis peternakan sapi potong pada kelompok secara kolektif dan juga sebagai tempat transaksi jual beli satu pintu.Transaksi satu pintu yang dimaksud adalah kegiatan jual beli sapi potong hidup 
maupun dalam bentuk daging melalui SPR sehingga kegiatan bisnis kelompok ternak yang dikelola terstruktur dan berjalan dengan baik (Penelitian, 2015)

Berdasarkan tujuan dari peranan SPR terhadap kelompok ternak, peneliti melihat bahwa kelompok ternak memerlukan pemetaan usaha untuk menentukan strategi yang dapat diterapkan oleh kelompok ternak. strategi yang akan diterapkandapat diperoleh melalui pemetaan model bisnis. Menurut (Amit, 2012) inovasi starategi untuk meningkatkan proses dan produk sering kali mahal dan memakan waktu, membutuhkan investasi di muka yang cukup besar dalam segala hal dari penelitian dan pengembangan sumber daya khusus, pabrik maupun peralatan baru, pengembangan $R \& D$, teknologi terbaru, dan bahkan seluruh unit bisnis baru. Semakin banyak perusahaan sekarang yang beralih pada inovasi pemetaan model bisnis sebagai alternatif atau pelengkap untuk produk atau inovasi proses. Sehingga, inovasi pemetaan yang paling memiliki dampak besar dalam bisnis adalah inovasi pada model bisnis.

(Osterwalder, 2012) mengatakan bahwa model bisnis dapat dijelaskan dengan sangat baik melalui sembilan balok bangun dasar yang memperlihatkan cara berfikir tentang bagaimana cara perusahaan menghasilkan uang. Sembilan balok bangun tersebut diletakkan pada sebuah susunan yang disebut Business Model Canvas. Business Model Canvas terbagi menjadi sembilan bagian utama, yaitu: Customer Segments (Segmen Pelanggan), Value Propositions (proposisi nilai), Channel (Saluran), Customer Relationships (Hubungan Pelanggan), Revenue Streams (Arus Pendapatan), Key Resources (Sumber Daya Utama), Key Activities (Aktivitas Kunci), Key Partnerships (Kemitran Utama) dan Cost Struktur (Struktur Biaya). Kemudian bagian-bagian ini dibagi lagi pada dua sisi yaitu sisi kiri (logika) dan sisi kanan (kreatifitas).

Pengembangan aplikasi visualisasi model bisnis telah dilakukan oleh (Osterwalder, 2012) dalam bentuk Business Model Canvas. Penggunaan Business Model Canvas dapat memberikan gambaran mengenai model bisnis perusahaan dan hubungan yang terjadi antar-blok dengan cara yang lebih atraktif. Business 9 Model Canvas juga membantu perusahaan untuk mengenali apa yang menjadi value proposition perusahaan, serta bagaimana membangun dan menjalankan key activities dan key resources dalam menciptakan value proposition dan mendapatkan revenue streams, memahami bagaimana produk dan jasa yang ditawarkan perusahaan dapat dikomunikasikan dengan baik kepada konsumen hingga sampai ketangan konsumen untuk dikonsumsi

\section{METODE PENELITIAN}

\section{Jenis penelitian}

Penelitian ini menggunakan jenis penelitian deskriptif kualitatif di mana dapat memberikan gambaran pemetaan model bisnis pada usaha kelompok ternak di bawah naungan SPR Muara Tigo Manunggal Kabupaten Muara Enim.Jadi penelitian ini mengarah pada pemaparan secara kualitatif sebagai acuan pengembangan usaha dengan pemetaan model bisnis yang dilakukan pada kelompok ternak.

\section{Subjek dan objek penelitian}

Volume2, Nomor 2, Bulan Oktober Tahun 2018|69 


\section{Journal of Food System and Agribusiness}

Subjek dalam penelitian ini adalah orang-orang yang menjadi sumber informasi di mana kriteria telah ditentukan oleh peneliti terlebih dahulu dan orang-orang yang terlibat langsung dalam proses penelitan ini yaitu peternak, kelompok ternak, SPR, mitra kelompok ternak dan juga pelanggan hasil ternak.

Objek penelitian ini merupakan inti dari penelitian yaitu pemetaan model bisnis kanvas yang dilakukan oleh kelompok ternak berdasarkan 9 elemen yaitu customer segment, value proposition, channel, customer relationship, reveneu streams, key resources, key activities, key partnertship, dan cost strukture.

\section{Jenis data}

Jenis data yang digunakan adalah jeis data kualitatif. Menurut (Moleong, 2007) data kualitatif tidak dinyatakan dalam bentuk angka atau bilangan. Jenis data kualitatif biasnya berupa kalimat yang menjelaskan suatu peristiwa atau kegiatan. Data ini untnk menjelaskan dan memberikan gambaran pemetaan model bisnis kanvas yang akan dilakukan pada usaha kelompok ternak.

\section{Sumber data}

Dalam penelitian ini, sumber data yang digunakan adalah sumber data primer dan sekunder.Sumber data primer diperoleh dari hasil wawancara, identifikasi lingkungan dan focus discussion group (FGD) terkait 9 elemen pada model bisnis kanvas.Data sekunder diperoleh dari hasil laporan, penelitian terdahulu dan data-data terkait dengan penelitian ini.

\section{HASIL DAN PEMBAHASAN}

\section{Pemetaan model bisnis kanvas usaha pada SPR}

Pemetaan model bisnis kanvas menunjukkan jenis produk apa saja yang dapat ditawarkan oleh masing-masing kelompok ternak yang ada pada SPR dengan sasaran yang berbeda. Kegiatan dalam mengolah produk hasil ternak menggunakan berbagai teknologi yang dapat diaplikasikan kelompok ternak.Pasar produk hasil olahan kelompok ternak dapat diperoleh dan diperluas melalui kerjasama SPR dengan instansi pendidikan dan perusahaan yang berkomitmen bersama SPR dalam mengembangkan produk hasil peternakan.Semua biaya yang dikeluarkan dan semua hasil pendapatan juga di masukkan dalam pemetaan model bisnis kanvas tersebut.Sehingga rencana anggaran biaya yang diperlukan dalam pengembangan SPR dapat dikelolah dengan baik.

Saat ini usaha yang dijalankan SPR yang menaungi kelompok ternak berupa produk sapi hidup dan kompos.Sasaran pasar yang dituju seperti penyedia qurban, petani kebun dan konsumen lokal yang ingin memelihara ternak sapi.Saluran pemasaran yang digunakan berupa kunjungan langsung dari konsumen dan personal selling.Berdasarkan produk yang ditawarkan, sumber daya utama yang harus dimiliki adalah ternak sapi dan lahan pakan ternak. Aktivitas utama dalam kegiatan peternakan adalah pemeliharaan ternak sebatas memberikan pakan, minum, menggembalakan, membersihkan kandang dan tidak diberikan perlakuan secara khusus sebagai bahan baku dalam bisnis peternakan sapi potong. Pada kegiatan usaha peternakan sapi potong, SPR bekerjasama dengan mitra seperti blantik/tengkulak dan peternak itu sendiri.Biaya yang 
dibutuhkan pada usaha saat ini hanya untuk membiayai kebutuhan perawatan kandang, tenaga kerja, kendaraan, instalasi listrik, dan kebutuhan obat-obatan untuk ternak. Biaya tersebut berasal dari pendapatan penjualan produk yang dipasarkan.

\begin{tabular}{|c|c|c|c|c|c|}
\hline \multirow[t]{2}{*}{$\begin{array}{l}\text { Mitra Utama } \\
\text { Petemak Sapi } \\
\text { Blantik } \\
\text { Peruashaen } \\
\text { Instansi Pendidikan } \\
\text { Dinas Petemaksan }\end{array}$} & $\begin{array}{l}\text { Aktivitas Utama } \\
\text { Betemak (Pemberian Pakan Dan } \\
\text { Perawatan Kesehatan Temak); } \\
\text { Pembuatan Palkan Fermentasi } \\
\text { Pembibitan Palan Segar } \\
\text { Pengolahan Kompos Menjadi } \\
\text { Biogas }\end{array}$ & \multirow{2}{*}{\multicolumn{2}{|c|}{$\begin{array}{l}\text { Produk Yang } \\
\text { Ditawarkan } \\
\text { Sapi Hidup } \\
\text { Kompos } \\
\text { Palkan Fermentasi } \\
\text { Palkan Segar } \\
\text { Biogas }\end{array}$}} & $\begin{array}{l}\text { Hubungan Dengan } \\
\text { Pelanggan } \\
\text { Layanan Personal } \\
\text { Potongan Harga } \\
\text { Layanan Khusus }\end{array}$ & \multirow{2}{*}{$\begin{array}{l}\text { Sasaran Pasar } \\
\text { Konsumen Lolsal } \\
\text { Penyedia Qurban } \\
\text { Petani Kebun } \\
\text { Masyarakat Umum } \\
\text { Petani Tanaman Pangan } \\
\text { Dinas Perkebunan Dan } \\
\text { Pertanaman } \\
\text { Peruahann }\end{array}$} \\
\hline & $\begin{array}{l}\text { Sumber Dava Utama } \\
\text { Lahan Pakan Temak: } \\
\text { Temak: Sapi } \\
\text { Petemak } \\
\text { Kelompok Temak: } \\
\text { Spr } \\
\text { Mesin Pencacah }\end{array}$ & & & $\begin{array}{l}\text { Saluran Pemasaran } \\
\text { Peraonal Selling } \\
\text { Kunjungan Konsumen } \\
\text { Penjualan Khusus Hari } \\
\text { Raya } \\
\text { Paar Temak: }\end{array}$ & \\
\hline \multicolumn{3}{|l|}{ Biaya } & \multicolumn{3}{|c|}{ Sumber Pemasukan } \\
\hline \multicolumn{3}{|c|}{$\begin{array}{l}\text { Biaya Tetap : Kandang, Tenega Kerja, Kendaraen, Instalasi Listrik } \\
\text { Biaya Variabel : Pakan, Obat-Obatan, Konsentrat, Vitamin, Kesehatan } \\
\text { Biaya Variabel : Perawatan Mesin Pengolahan }\end{array}$} & \multicolumn{3}{|c|}{$\begin{array}{l}\text { Hasil Penjualan Sapi Dan Kompos } \\
\text { Haail Penjualan Pakan Fementaai, Palkan Segar Dan Biogas }\end{array}$} \\
\hline
\end{tabular}

Gambar 1. Model Usaha Kanvas Kelompok Ternak SPR

Berdasarkan hasil pemetaan rencana pengembangan usaha yang dilakukan SPR MTM mengemukakan bahwa:

1. Pada elemen cusomer segment terdapat pengembangan jaringan pasar dari sasaran pasar sebelumnya. Pengembangan jaringan pasar menjangkau yang lebih luas seperti masyarakat umum dapat langsung melakukantrasaksi jual beli ternak terhadap SPR. Perusahaan juga menjadi jaringan pasar yang diembangkan, karena melalui perusahan hasil pengolahan limbah ternak dapat tmemiliki nilai jual yang lebih tinggi. Petani tanaman pangan dan dinas perkebunan dan pertanaman juga menjadi sasaran pasar SPR. Hal ini tidak lepas dari kerjasama antara mitra kerja dengan SPR.

2. Pada elemen value Proposition terdapat beberapa produk baru yang akan ditawarkan. Produk tersebut berupa pakan fermentasi, pakan segar dan biogas. Produk ini dibuat berdasarkan sasaran pasar yang dimiliki seperti petani tanaman pangan, perusahaan dan beberapa instansi terkait. Produk ini diciptakan untuk memenuhi kebutuhan sasaran pasar yang akan dituju. Memenuhi produk kebutuhan pasar menjadi keunggulan dari elemen ini. Elemen channel merupakan saluran pemasaran yang dilakukan dengan mengadakan penjualan khusus seperti pameran dan penjualan khusus ternak. Elemen ini memetakan bagaimana SPR menarik perhatian pelanggan dengan mengadakan pasarpasar khusus. Pasar khusus tersebut berupa memberikan pelayanan khusus kepada pelanggan yang telah bekerjasama dan menarik pelanggan baru dengan mengadakan penawaran khusus.

3. Berdasarkan elemen channel tersebut, pada elemen customer relationship terhadap pelanggan dapat dibangun dengan cara memberikan pelayanan khusus seperti memberikan potongan harga. Hubungan yang baik dengan pemasok akan memudahkan kita mencari informasi mengenai harga, 


\section{Journal of Food System and Agribusiness}

selain itu pemasok juga dapat memberikan layanan antar dan memberikan diskon khusus untuk pembelian dalam jumlah besar (Kustina, 2008)

4. Pada elemen revenue streams menunjukkan dari mana saja sumber pendapatan yang diperoleh SPR. Semua sumber pendapatan diperoleh dari hasil penjualan prodk yang ditswarkan, baik itu produk lama maupun poduk baru yang dikembangkan. Semua sumber pendapatan akan dimasukkan kedalam elemen ini, sehingga terlihat jelas seberapa besar jumlah penghasilan yang diperoleh SPR dalam mengembangkan usaha ternak sapi potong.

5. Berdasarkan produk baru yang dikembangakan, maka key resource menambahkan beberapa poin yang harus dipenuhi. Sumber daya berupa sebuah kelompok ternak yang aktif dan beberapa teknologi yang dibutuhkan untuk mengolah bahan baku yang ada menjadi sebuah produk yang dapat dikembangkan. Teknologi berupa mesin pencacah pakan akan sangat dibutuhkan dalam pengembangan rencana pengembangan usaha SPR.

6. Dalam melakukan semua kegiatan pada elemen sebelumnya, pada pemetaan model bisnis kanvas ini juga memetakan key activites yang harus dilakukan SPR untuk memenuhi kebutuhan elemen sebelumnya yang telah dipetakan. Kegitan pembuatan pakan fermentasi dan pengolahan kompos menjadi biogas menjadi kegitatan tambahan yang harus dilakukan SPR untuk mencapai sasaran pasar yang telah direncanakan.

7. Semua kegiatan pada pemetaan model bisnis ini tidak terlepas dari kerjasama key partnert. Bekerjasama dengan mitra harus dipertimbangkan oleh SPR. Mitra tersebut harus memiliki kontribusu terhadap pengembangan usaha yang akan dikembangkan SPR. Salah satu fungsi dari mitra utama adalah menjadi jaringan perluasan pasar, sehingga mitra tersebut tidak hanya memerikan dukungan kepada SPR berupa bantuan material, namun juga berkontribusi dalam pengembangan usaha ternak SPR secara langsung. Mitra yang dibutuhkan SPR seperti perusahaan yang mampu berkomitmen dengan tujuan utama SPR yang akan dicapai dan beberapa instansi terkait yang mendukung kegitan usaha pengembangan ternak SPR.

8. Biaya yang diperlukan pada kegiatan pengembangan usaha ternak SPR akan dirincikan pada elemen cost structure. Semua rincian biaya yang dibutuhkan akan dipetakan pada elemen ini.biaya pemeliharaan ternak, biaya pengolahan produksi, biaya perawatan teknologi hingga biaya yang dibutuhkan untuk memberikan nilai kepada pelanggan akan dirincikan pada elemen ini. SRP membutuhkan banyak biaya pada kegiatan pengembangnnya, namun dapat diorganisir dengan adanya rincian biaya yang dipetakan, sehingga tidak melebihi dari kapasitas kemampuan SPR dalam menggunakan anggaran.

Pemetaan usaha ternak SPR dapat menjadi strategi yang tepat untuk mengembangkan usaha ternak, sehingga tujuan SPR mencapai tujuan untuk swasembada pangan khususnya daging dan mensejahterakan anggota yang ada pada SPR akan tercapai sesuai dengan rencana yang telah dibuat. Pengembangan produk tersebut harus didukung dengan sumber daya utama seperti mesin pencacah dan sumber aya manusia yang ada di kelompok ternak dan SPR. Pengembangan juga menuntut peternak menambah aktivitas utama seperti 
pembuatan pakan fermentasi, pembibitan pakan segar, dan pengolahan limbah ternak menjadi biogas. Pengembangan usaha yang dilakukan oleh kelompok ternak bersama SPR MTM melibatkan mitra seperti perusahaan, instansi pendidikan dan dinas peternakan. Mitra tersebut akan membentu memperluas jaringan pasar untuk produk yang dihasilkan kelompok ternak bersama SPR.

Biaya yang perlu dikeluarkan dalam pengembangan usaha kelompok ternak sapi potong juga dapat dipetaka dalam model bisnis kanvas. Biaya tetap dan biaya variabel yang akan dikeluarkan selama pengembangan bisa dikelolah dengan baik, sehingga tidak terjadi kelebihan atau kekurangan anggaran yang harus dikeluarkan. Pemeliharaan sarana dan prasarana, biaya transportasi, biaya obat-obatan, vitamin, konsentrat dll, dapat diplotkan dengan baik sehingga kelompok ternak dapat menggunakan anggaran biaya tersebut secara maksimal dengan penggunaan yang tepat.

\section{KESIMPULAN (DAN SARAN [Optional])}

\section{Kesimpulan}

Pemetaan model bisnis kanvas pada usaha ternak SPR mengembangkan beberapa produk baru untuk memenuhi kebutuhan konsumen yang menjadi target pasar.Adanya kegiatan tambahan pada pengembangan usaha ternak SPR menuntut untuk mengeluarkan biaya tambahan dan kegitan tambahan. Biaya yang dikeluarkan akan tertutupi oleh sember penghasilan yang bertambah. Semua kegitan tidak terlepas dari kontribusi mitra yang bekerjasama dengan SPR untuk mengembangkan usaha ternak SPR.

\section{DAFTAR PUSTAKA}

Amit, R. Zott, C. (2012). Creating value through business model innovation. MIT sloan management review edisi spring, 53(3). Retrieved sept 18, 2013, From http:/management.whatron.upenn.edu/ amitresearch/docs/2012/Amit_Creating_Value_Business_Model_Innovation.pdf.

Pertanian, B. L. (2009). Model Penerapan Teknologi Litbang Sapi Potong Mendukung PSDS. Badan Penelitian dan Pengembangan Pertanian, Jakarta.

Clark, T., Osterwalder, A., \& Pigneur, Y. (2012). Business model you: a one-page method for reinventing your career. John Wiley \& Sons.

Kustina, S. (2008). Optimalisasi Pengelolahan Retribusi Parkir Dalam Rangka Peningkatan Pendapatan Asli Darerah (Studi di Kawasan Kota Malang). Arena Hukum. 1(1): 1-1.

Moleong, L. J. (2007). Metodologi Penelitian Kualitatif edisi revisi Bandung: PT Remaja Rosdakarya Offset. ISBN 979-514-051-5.

Osterwalder A, Pigneur Y. 2012. Business Model Generation. New Jersey (US): John Willy \& Sons, Inc.

Penelitian, L. Pengabdian kepada Masyarakat Institut Pertanian Bogor. 2015. Buku panduan sekolah peternakan rakyat (SPR 1111). Bogor: Institut Pertanian Bogor. 
Peternakan, D. J., \& Hewan, K. (2015). Pedoman Sentra Peternakan Rakyat. Jakarta: Kementerian Pertanian RI.

Yusdja, Y., Sajuti, R., Suhartini, S. H., Sadikin, I., Winarso, B., \& Muslim, C. (2004).Pemantapan program dan strategi kebijakan peningkatan produksi daging sapi. Laporan Akhir. Puslitbang Sosial Ekonomi Pertanian, Bogor, 10.Ditjennak (direktorat jendral peternakan). 2009. Statistik peternakan. Ditjennak, jakarta. 